\title{
Monitoring the Transport on the Ciobănuș Forest Road within the Bacău Forestry Department
}

\author{
Ioan BITIR \\ Transilvania University of Brasov, Romania, bitirioan@yahoo.com \\ Elena Camelia MUSAT \\ Transilvania University of Brasov, Romania, elena.musat@unitbv.ro \\ Aurel LUNGULEASA \\ Transilvania University of Brasov, Romania, lunga@unitbv.ro \\ Valentina Doina CIOBANU \\ Transilvania University of Brasov, Romania, ciobanudv@unitbv.ro
}

\begin{abstract}
Compared to other types of transport, log transport has its own characteristics related to both the transport route and the means of transport. Because, over time, both the routes used to transport timber and the means of transport have constantly evolved, being adapted to the new requirements, specialists in the field always seek to extend the period of operation of forest roads, especially that, in the case of the present, most of them have been designed and built to withstand lower traffic in terms of intensity and frequency. Thus, in order to behave as well as possible in operation, forest roads must be made more precisely the geometric and constructive elements of forest roads and must take into account the constructive characteristics and the movement of vehicles to travel on these roads. Considering the current situation, a very important one, it was considered opportune to research a forest road from the perspective of the traffic on it, recorded for a longer period of time. Thus, the research was carried out on a valley road from the administration of the Bacău Forestry Department - the Ciobănuș forest road. Following the centralization and interpretation of the data, it resulted that the annual distribution of transported volumes is approximately equal and no significant variations were found between 2014 and 2018 and that annually, on the Ciobănuș forest road, a specific tonnage transits the main forest roads, which supports , once again, the accentuated degree of degradation and the rapidity of degradation on this road, due to an insufficiently dimensioned superstructure, which cannot support the annual volumes transited.
\end{abstract}

\section{Keywords}

forest road, traffic monitoring, forest truck, wood mass, log transport

\section{Introduction}

The Ciobănuș forest road is located outside the village of Asău commune, Bacău county, Romania. The objective is a valley road that runs along the Ciobănuș river valley, a right tributary of the Trotuș River (Siret river basin), being a main road, with a platform of 4.5 meters and a road of 3.5 meters. The forest road was put into operation in 1973.

The forest road under study was taken over, in 1994, by the Bacău Forestry Directorate from the I.F.E.T. Bacău, its delivery/receipt being made on the basis of a report, the delivery not being accompanied by the technical book of the objective. After 1994, only maintenance works were carried out on the Ciobănuș forest road, and no current repairs, capital repairs or rehabilitations were carried out. Also, during the last two decades, the forest road has been affected by numerous torrential floods (the most significant in 2005, when the objective was 50\% disastrous, becoming impassable), which led to the current technical condition of the road.

The forest transport network is used intensively only in certain periods of the year, more precisely outside the periods of exploitation restrictions $[1,2]$ when, on the forest roads, the most important quantities of wood, consisting of materials, most of the times, voluminous, degradable and with relatively high weight and variable in time $[3,4]$, which require specialized transport vehicles.

It should also be mentioned that, although the forest transport network consists of three categories of roads, depending on their importance and functionality - main roads, main roads and secondary roads $[3,5-8]$, which have different technical characteristics depending on the forest area served and the 
annual traffic, the maximum total mass allowed for lorries with trailers transiting on them is restricted to 38 tonnes $[8,9]$, as most of the current forest roads have non-rigid road structures, made of stony materials, most of the time the clothing is simple hardening of one or two layers $[3,5,6,8]$.

On the other hand, the expansion of forest car transport (over $90 \%$ of the transported volume is carried out by car - i.e., on roads $[3,10]$, and the gradual abandonment of other modes of transport [7, $10,11,12]$ is justified by the advantages of the forest road network, such as $[3,6,8,10]$ :

- shows a better adaptation to different terrain conditions, which offers the possibility to penetrate deeper into the forest (thus a reduction of the average collection distance);

- ensures the continuous development of the activities necessary for the sustainable management of forests;

- offers advantageous technical and economic premises for the superior and integral capitalization of wood and other forest products;

- ensures the transport of wood, as the main product of the forest, in economic conditions, even in the case of small quantities of wood.

In addition, the analysis of the state and behaviour of the forest transport network over time must take into account the means of transport transiting the roads and the volumes transported, as it is known that the degradation of forest roads may be exacerbated by different factors either by the faulty design or execution of the works, or by improper maintenance, or even by the circulation of heavy trucks $[13,14]$ which require the transport network.

Regarding the composition of the traffic, it is mentioned that a wide range of means of transport circulates on the forest roads, some destined for the transport of workers and forestry personnel, others destined for forest accessory products and various goods necessary for a good management (seedlings, pheromone races, etc.) and, most of them, intended for the transport of wood, in various forms (round wood, split wood, wood chips, manganese [3]. On the other hand, there are also automobile vehicles, with animal traction, that run on forest roads, but this transport is low and is not important for establishing the geometric elements of forest roads, the demands produced by these transports being insignificant.

Basically, they can drive on forest roads $[3,6,10]$ :

- animal-drawn vehicles;

- ordinary motor vehicles (lorries, with or without trailer, and vans), with load capacities of 8 to 18 tonnes. They are used for the general transport of goods, but also for transporting split wood, wood chips, manganese or ancillary products and even workers;

- forestry road trains (ATF), means of transport specialized in the transport of round wood. They consist of a tractor unit and a single-axle or semi-trailer (ATF 25-30 t). The length of the semitrailer can be changed (by moving the axle of the semi-trailer in relation to its longitudinal axis) depending on the length of the wood assortments to be transported. In practice there are many situations in which the length of the semi-trailer is not adjusted correctly, which makes the load distribution on the two axles (tractor and semi-trailer) not uniform;

- forestry platforms (APT), in general, used to transport both round and felled timber. In addition, it has a very important advantage, namely that the loads are much better distributed on the axles, which makes the car platform fit more easily in curves;

- dump trucks (with load capacities of $6.5 ; 8 ; 10.5$ or 16 tons), used for the transport of quarry and ballast products, necessary for the maintenance of existing forest roads or the construction of new roads.

Compared to the mentioned vehicles, on the forest roads there are also a series of service or personal vehicles of those involved in forest management (forestry personnel, control bodies) or of various economic agents that either pre-set services for the forest administrator or the adjudicator exploitation parquets in the area.

For the above reasons, it was considered appropriate to study the traffic on the Ciobănuș forest road, through monitoring of wood transports, which is the real objective of the paper. This has as final goal, the knowledge of the deterioration of the road taken in work, in order to manage the remediation and restoration operations. 


\section{Location and Research Methodology}

There are several aspects to be mentioned regarding the technical condition of the Ciobănuș forest road, namely:

- as a result of the torrential floods that affected the body of the road, in the areas near the minor bed of the Ciobănuș river, the width of the platform no longer presents the dimensions related to a main road;

- the geometric elements of the road no longer ensure the development of a safe traffic;

- the location of the primary platforms in the immediate vicinity of the road or even on its platform generates a consistent supply of non-compliant material (earth, mud, debris, etc.) that contaminates the superstructure of the forest road, with direct consequences affecting its loadbearing capacity.

In order to highlight the traffic structure, on the Ciobănus forest road, a daily traffic monitoring was performed, for a long period of time, more precisely for five and a half years (from 2014 to the first semester of 2019). The daily data collected consisted in mentioning, for each timber transport carried out, the following information (table 1): date, registration number of the platform / trailer, number of the consignment note (s) accompanying the wood, consignee of the consignment, assortment transported, the transported volume broken down by species (resinous and / or deciduous), the information being centralized in an Excel database. The calculation of the transported tonnage was performed with the following values for the specific weights: 0.87 tons $/ \mathrm{m}^{3}$ for softwoods, 1 ton $/ \mathrm{m}^{3}$ for hardwoods and 1.7 tons $/ \mathrm{m}^{3}$ for ballast.

\section{Results and Discussion}

As a result of special technical development, the means of transport have undergone a rapid modernization, which has led to an increase in the maximum authorized payload from 2.5 tons in 1962 to over 46.5 tons in 2018 (equivalent to 60 tons mass total). Although the payload of forestry platforms has increased exponentially (figure 1), the technical parameters of forest roads have not changed significantly, the entire forest road network being designed for a maximum total allowable load of 24 tons (38 tons for roads built after 2015).

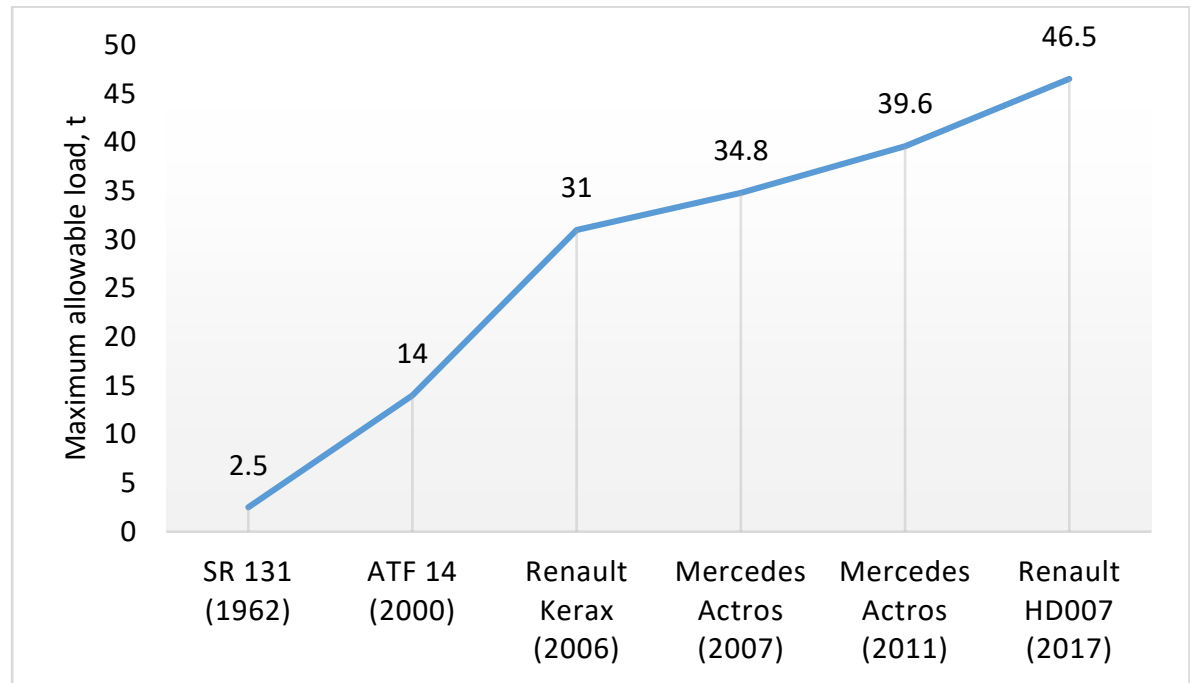

Fig. 1. In-time evolution of tonnage for forest trucks (1962 - 2017)

Following the centralization of the collected data, it resulted that, for the period 2014-2018, on the forest road under study, a volume of $171,691 \mathrm{~m}^{3}$ was transported with a tonnage of $153,246 \mathrm{~m}^{3}$, equivalent to an average annual volume of $34,338 \mathrm{~m}^{3}$, with a mass of 30,650 tons. The total mass of the "vehicle-volume of transported wood" was 235,093 tons, the average annual equivalent of 47,018 tons. As can be seen from the data presented in table 1, the annual distribution of the transported volumes is approximately equal and no significant variations were found. 
RECENT, Vol. 22, no. 1(63), 2021

Table 1. Synthesis of data regarding the volume and tonnage transported in the period 2014-2018 on the Ciobănuș forest road

\begin{tabular}{|c|c|c|c|}
\hline Year & Volume $\left[\mathrm{m}^{3}\right]$ & Tonnage transport [tons] & Tonnage transited [tons] \\
\hline 2018 & 35297 & 30717 & 45428 \\
\hline 2017 & 30827 & 28851 & 43383 \\
\hline 2016 & 35192 & 32065 & 49373 \\
\hline 2015 & 34607 & 29871 & 46579 \\
\hline 2014 & 35767 & 31742 & 50329 \\
\hline TOTAL & 171691 & 153246 & 235093 \\
\hline
\end{tabular}

As it results from the diagrams shown in figures $2-6$, the monthly distribution of the transported volumes is similar in the five years, respectively a higher volume is registered in January-March, followed by a decrease in April-September and a return in the middle of the fourth trimester. This distribution is caused by three exploitation restrictions for certain types of products and species.

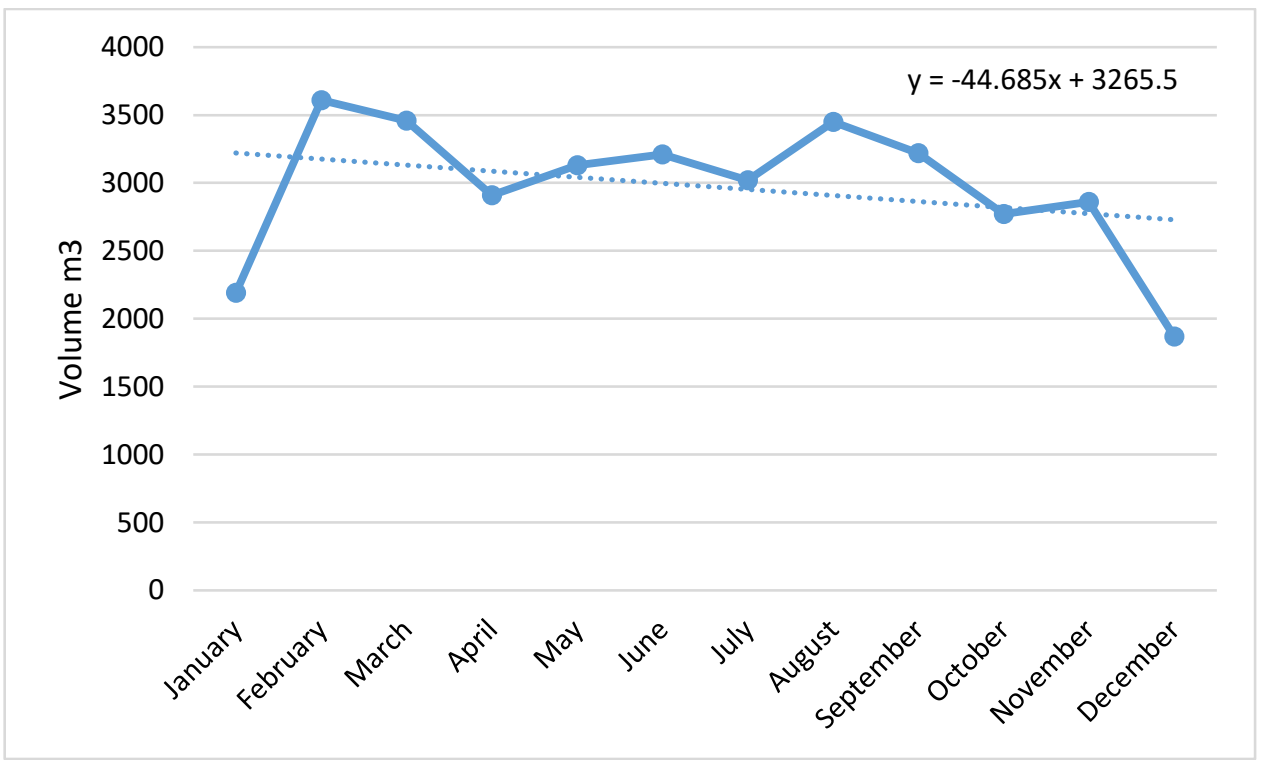

Fig. 2. Monthly distribution of volumes transported in 2014

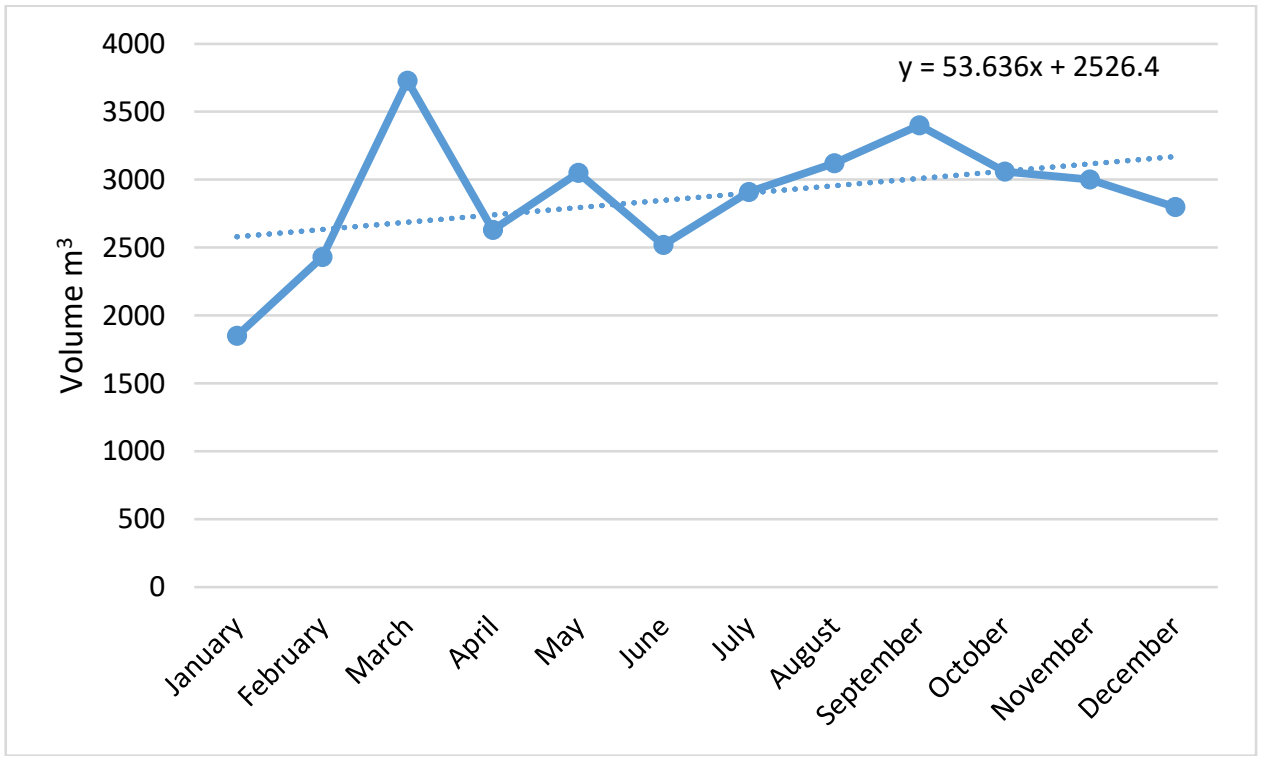

Fig. 3. Monthly distribution of volumes transported in 2015 


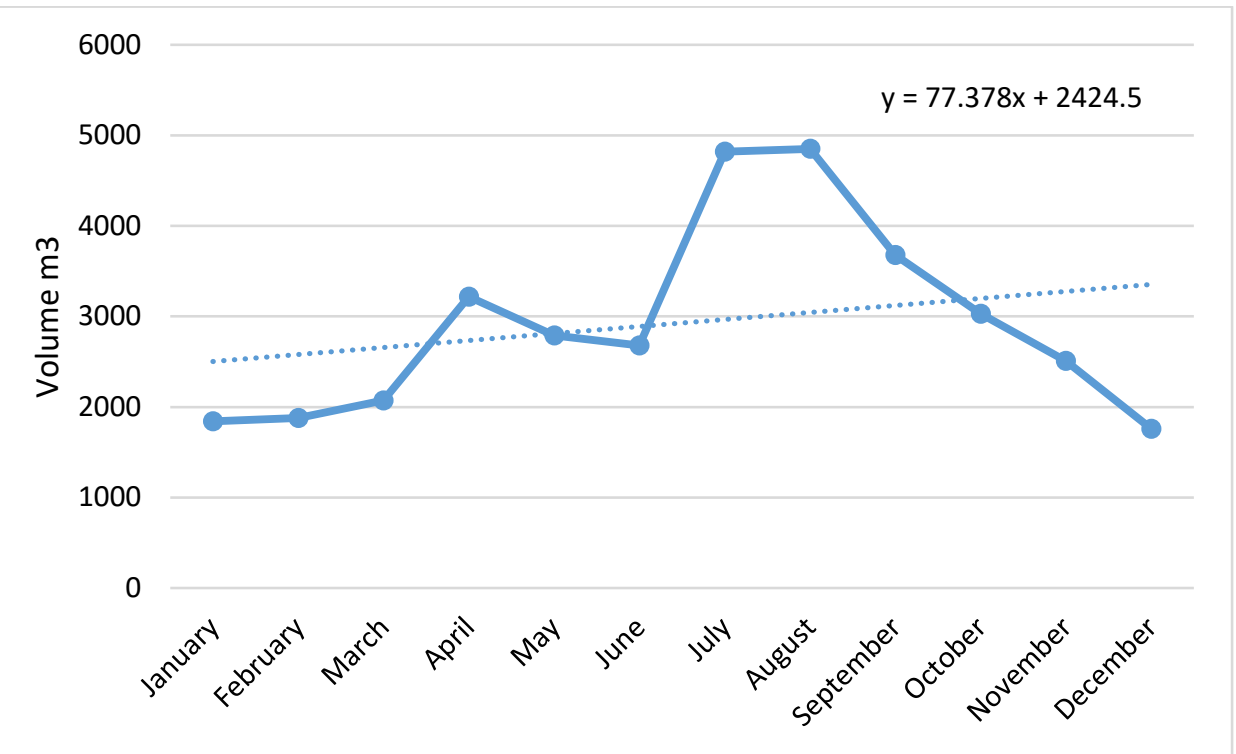

Fig. 4. Monthly distribution of volumes transported in 2016

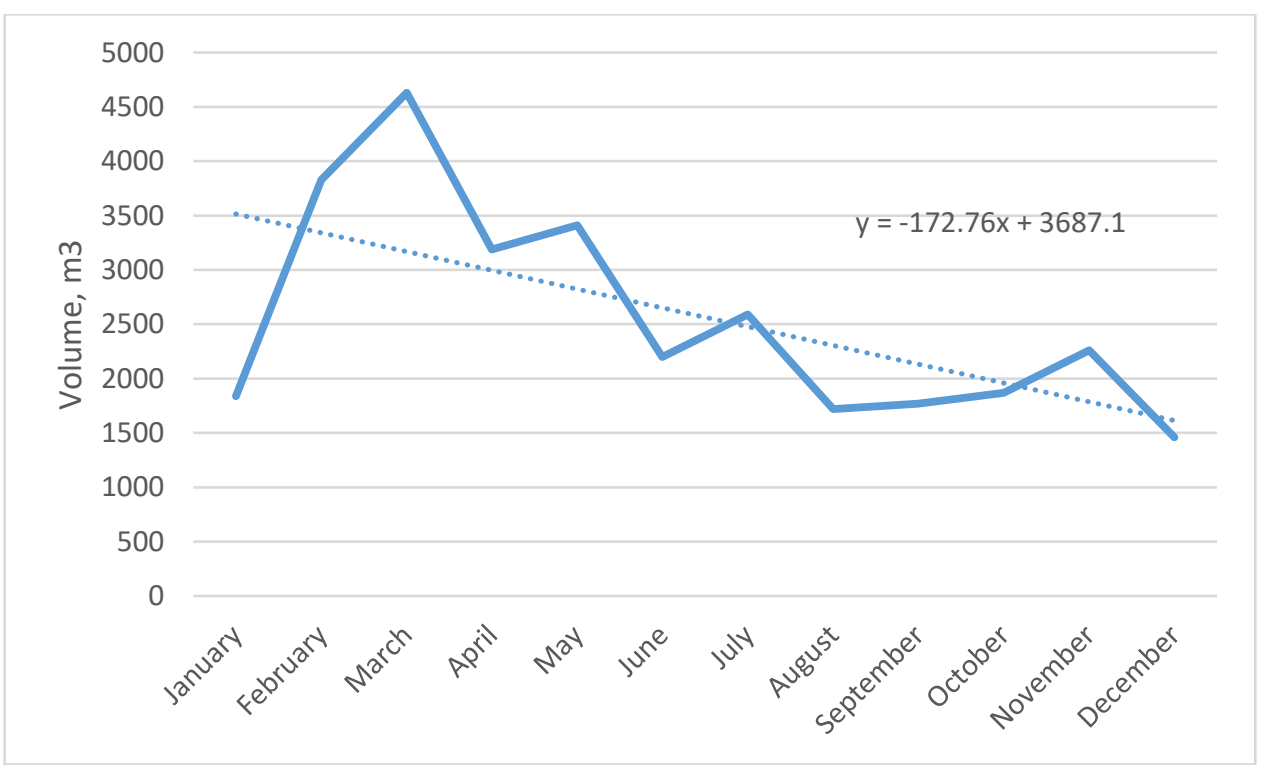

Fig. 5. Monthly distribution of volumes transported in 2017

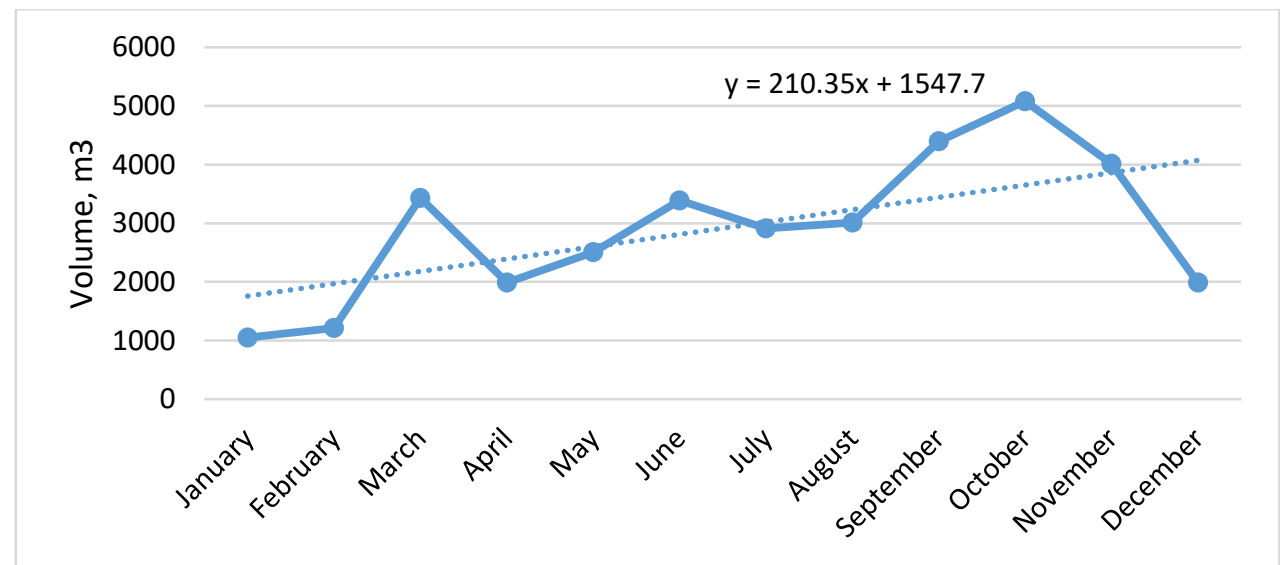

Fig. 6. Monthly distribution of volumes transported in 2018 
In the period 2014-2018 (table 2), there is a significant increase in the transport of timber with means of transport with a total mass below 5 tons. Although, in the share of total transport, the use of these types of vehicles is insignificant [16], representing only $2 \%$, however, they are generally used by individuals for the purchase of firewood ( $90 \%$ of the volume transported with these means of transport corresponds to firewood - table 3). The significant increase in the transport of firewood in the period 2014-2018 was determined by the increase in the price of firewood, but also by the decrease in the quantities of wood of illegal origin.

Table 2. Analysis of the transport performed in the period 2014 - 2019 from the perspective of the truck of transport used

\begin{tabular}{|l|r|r|r|c|c|}
\hline \multirow{2}{*}{ Year } & \multicolumn{5}{|l|}{ Truck tonnage range [tons] } \\
\cline { 2 - 6 } & $0 \ldots 5$ & $5 \ldots 12$ & $12 \ldots 24$ & $24 \ldots 38$ & Over 38 \\
\hline 2014 & 367 & 1044 & 892 & 9740 & 23724 \\
\hline 2015 & 526 & 859 & 621 & 7628 & 24973 \\
\hline 2016 & 581 & 736 & 431 & 6170 & 27275 \\
\hline 2017 & 947 & 428 & 216 & 5415 & 23821 \\
\hline 2018 & 1341 & 91 & 344 & 4586 & 28935 \\
\hline 2019 & 374 & 181 & 254 & 1673 & 13581 \\
\hline TOTAL [tons] & 4136 & 3339 & 2758 & 35212 & 142309 \\
\hline
\end{tabular}

Table 3. Transport of wood with truck with a total mass of less than 5 tons

\begin{tabular}{|c|c|c|c|}
\hline \multirow{2}{*}{ Year } & \multicolumn{2}{|l|}{ Tonnage truck range of 0.5 tons } & \multirow{2}{*}{ Fire wood [\%] } \\
\cline { 2 - 3 } & Volume total $\left[\mathrm{m}^{3}\right]$ & From which fire wood $\left[\mathrm{m}^{3}\right]$ & \\
\hline 2014 & 367 & 292 & 80 \\
\hline 2015 & 526 & 455 & 87 \\
\hline 2016 & 581 & 499 & 86 \\
\hline 2017 & 947 & 864 & 91 \\
\hline 2018 & 1341 & 1230 & 92 \\
\hline
\end{tabular}

It should be noted that the Forest Road Design Regulation [9] legislates a maximum total permissible load for trucks with trailers, of maximum 38 tons. Reported to this mention in the regulations, it is reported that most of the timber transport is done with vehicles with a trailer with a maximum total mass exceeding 38 tons, which explains somewhat the degradations recorded on the Ciobănuș forest road

If we take into account the design regulations prior to $2015[9,14,16]$, based on which, in fact, the design of the Ciobănuss forest road was carried out, and taking as a benchmark a maximum tonnage allowed for 25 tonnes (road-train assembly, trailer and timber transported), the situation is as follows:

- the volume transported by road trains with a mass over 25 tons: 29,062 $\mathrm{m}^{3}$ ( $94 \%$ of the total);

- volume transported by road mass under 25 tons: $1,764 \mathrm{~m}^{3}(6 \%)$.

Over time, the maximum permissible payload and, implicitly, the maximum total weight of trucks, has increased significantly in a very short time, most of the timber transport being carried out with means of transport where the total mass exceeds the expected value through the Forest Road Design Norm $[9,17,18]$.

\section{Conclusions}

The annual distribution of transported volumes is approximately equal and no significant variations were found between 2014 and 2018.

The number of races that transited the Ciobănuș forest road experienced a slow but continuous decrease, but the decrease of the transported volume was much smaller.

Although the volume of timber transported did not change significantly, the significant decrease in the number of journeys led, in fact, to an increase in the average volume transported per journey and, 
consequently, in the average tonnage.

Corroborating the monthly distribution of timber transport on the Ciobănuș forest road, in 2017, with the data of the main climatic elements registered during the same year, it can be stated that the transport with the highest intensity takes place between October and March, characterized from a climatic point of view, of low temperatures, relatively high humidity, days with high cloudiness, high wind speeds. Also, towards the end of this interval, the forest road is affected by the freeze-thaw phenomenon.

Annually, on the Ciobănuș forest road, a tonnage specific to the main forest roads transits, which supports, once again, the accentuated degree of degradation and the rapidity of degradation on this road, due to an insufficiently dimensioned superstructure, which cannot sustain transited annual volumes.

Road traffic on forest roads is the main cause of their technical wear and tear.

\section{References}

1. Ciubotaru A. (1998): Exploatarea pădurilor (Forest Exploitation). Lux Libris, ISBN 973-9240-73-9

2. Horodnic SA. (2003): Bazele exploatării lemnului (Basis of wood exploitation). Editura Universității Suceava, ISBN 973-8293-93-6

3. Olteanu N. (1996). Proiectarea drumurilor forestiere (Design of the forest roads). Lux Libris, ISBN 973-9240-01-1

4. Zanuncio A.J.V., Carvalho A.G., da Silva M.G., Lima J.T. (2017): Importance of wood drying to the forest transport and pulp mill supply. CERNE, e-ISSN 2317-6342, Vol. 23(2), pp. 147-152, http://dx.doi.org/10.1590/ 01047760201723022223

5. Alexandru V. (2000): Construcția și întreținerea drumurilor forestiere (Construction and maintenance of forest roads). Infomarket, ISBN 973-998-276-X

6. Bereziuc R., Alexandru V., Ciobanu V., Ignea Gh. (2008): Elemente de fundamentare a normativului de proiectare a drumurilor forestiere (Elements of substantiation of the forest road design norm). Editura Universității Transilvania, ISBN 978-973-598-318-5

7. Zarojanu D. (2010): Instalații de transport (Installation of transport). Editura Universității Suceava, ISBN 978973-666-330-7

8. *** (2012): Normativ privind proiectarea drumurilor forestiere (Norm of the forest road design). Indicative PD003-11, approved by Order of the Minister of Environment and Forests no. 1374 from 04.05.2012

9. Bitir I., Musat E.C., Derczeni R.A., Ciobanu V.D. (2019): The influence of the increased tonnage upon the superstructure of forest roads. Proceedings of SGEM 2019, Vol. 19, ISBN 978-619-7408-82-9, ISSN 1314-2704, pp. 853-860, DOI: $10.5593 /$ sgem2019/3.2/S14.110

10. Popovici V., Bereziuc R., Clinciu I. (2003): Extinderea rețelei de drumuri pentru accesibilizarea fondului forestier și, în general, a pădurii (Expanding the road network to make the forest fund and the forest in general more accessible). Bucovina Forestieră, e-ISSN 1582-3725, Vol. 11(2), pp. 36-40

11. Bereziuc R., Alexandru V., Ciobanu V., Ignea Gh., Abrudan I., Derczeni R. (2006): Ghid pentru proiectarea, construcția și întreținerea drumurilor forestiere (Guide for the design, construction and maintenance of forest roads). Editura Universității Transilvania, ISBN 978-973-635-708-4

12. Bereziuc R. (2004): Realizări și perspective în domeniul căilor forestiere de transport (Achievements and perspectives in the field of forest transport routes). Annals of the "Stefan cel Mare" University of Suceava, Section Silviculture, ISSN 1223-0626, no. 2, pp. 9-14

13. ${ }^{* * *}$ (2012): Normativ pentru reabilitarea drumurilor forestiere (Norm for the forest roads rehabilitation). Indicative RD-001-11, approved by Order of the Minister of Environment and Forests no. 1373 from 04.05 .2012

14. Potočnik I., Pentek T., Pičman D. (2005): Impact of traffic characteristics on forest roads due to forest management. Croatian Journal of Forest Engineering, ISSN 1845-5719, Vol. 26(1), pp. 51-57

15. *** (2002): Normativ privind proiectarea și execuția împietruirilor drumurilor de pământ. Conditiii de calitate (Normative regarding the design and execution of paving dirt roads. Quality conditions). Indicative AND$582 / 2002$

16. Acuna M. (2017): Timber and biomass transport optimization: a review of planning issue, solution techniques and decission support tools. Croatian Journal of Forest Engineering, ISSN 1845-5719, Vol. 38(2), pp. 279-290

17. Musat E.C., Iancu B.I., Derczeni R.A., Ciobanu V.D. (2019): Analysis of transport distances and wood volumes purchased by a woodworking company. Proceedings of SGEM 2019, Vol. 19, ISBN 978-619-7408-82-9, ISSN 1314-2704, Iss. 3.2, pp. 617-624, DOI:10.5593/sgem2019/3.2/S14.080 